\title{
PRAGMATIC AND RHETORICAL STRATEGIES IN THE ENGLISH-WRITTEN JOKES
}

\author{
Dyah Rochmawati \\ Universitas PGRI Adi Buana Surabaya, Indonesia \\ dyra.hadi@yahoo.com
}

First received: 28 January 2017

Final Proof Received: 29 May 2017

\begin{abstract}
Understanding verbal jokes in English is problematic for English as Foreign Language (EFL) readers since understanding the jokes requires understanding their linguistic, cultural and social elements. Since a joke constitutes a complex and paradoxical phenomenon, it needs multiple approaches of analyses - such as pragmatic and rhetorical analyses - in order to investigate the multiple layers of meanings it carries. Recently there has been a shift in humor studies, emphasizing linguistic humors and involving the field of rhetoric. These studies, however, have mostly addressed the connection between rhetoric and spoken jokes in persuasion. The present study therefore applied Austin's Speech Act Theory (1975) and Grice's Cooperative Principles (1957), and Berger's rhetorical techniques (1993) to crack the funniness of the written jokes. Specifically, the study aims at describing: how the (1) rhetorical and (2) pragmatic strategies are used in the jokes, and (3) how the pragmatic and rhetorical strategies complement to create humor. The study employed a qualitative research method. Some jokes were purposively selected from the Reader's Digest and two online sources: http://jokes.cc.com/, and http://www.ajokeaday.com/. Document studies were the means of data collection. The collected data were then analyzed using a qualitative content analysis. The results showed that that there was a relationship between the two pragmatic theories, i.e., Speech Act Theory and Cooperative Principles, and Berger's rhetorical techniques. The results offered an alternative reading and richer understanding of how written jokes employed pragmatic and rhetorical strategies to advance their rhetorical objectives and humor functions.
\end{abstract}

Keywords: pragmatics; rhetorical strategies; English-written jokes

Humor is a complex and universal human phenomenon. Since the earliest times, it has performed an essential role in human interaction (Kao, Levy \& Goodman, 2015). In addition, human beings are the only species that laughs (Ashipaoloye, 2013).

There are a number of functions of humor, as humor is an important tool to achieve certain purposes and commonly used as a discourse strategy. Humor can be broken down into two basic functions: unification and division. Unification refers to the idea that humor is a tool to construct, promote, strengthen, and unite communicators. Humor provides a social medium through which information can be shared and friendships can be made. Humor, therefore, has a versatile role to promote solidarity or social cohesion. The division function points to hierarchy building. In this instance, humor may send "an explicit message of superiority."(Meyer, 2000, p. 311) Humor reflects the power division and status relations between jokers and their targets (Kuipers, 2008, p. 367).

Humor research draws upon a wide range of disciplines: anthropology, linguistics, medicine, psychology, philosophy, sociology and women's studies. The field of the linguistics of humor is in many ways still in its infancy (Attardo, 2014). For the past five years, linguistic humor research in language has shed light on humorous discourse, for instance, dialogues of the American TV series The Big Bang Theory (Ma \& Jiang, 2013), Indonesian stand-up comedy (Afidah \& Wahyudi, 2014), Romanian parliamentary discourse by a controversial political figure of Romanian politics, Corneliu Vadim Tudor (Săftoiu \& Popescu, 2014), Obama's most memorable speeches (Kayam, 2014), a computational model of linguistics humor in puns (Kao et al., 2015), Dudley's political cartoons (Mwetulundila \& Kangira, 2015), English advertisements in India (Chetia, 2015), persuasion in Jesus Christ's Humor (Al-Ameedi \& Abdulmajeed, 2016), and controversial humor (Hietalahti, 2016).

In Indonesia, humor has also been studied from the linguistic perspectives. Graf (2003) studied humor in Indonesian politics, in particular, Abdurrahman Wahid's (popularly known as Gus Dur) jokes. Another was done on Indonesian standup comedy (Afidah \& Wahyudi, 2014). There was also a study on sexual humor in Indonesia (Lesmana, 2015).

Most of those linguistic humor studies address the analysis of spoken jokes, since humor primarily consists of jokes (Sen, 2012). There are two kinds of humor: spoken and written (Golchi and Jamali, 2011). There are differences between spoken and 
written language; the written language is relatively more complex than spoken one. Furthermore, written language has more grammatical complexity-usually contains longer words, lexically more dense, and has a more varied vocabulary (Willis, 2003). The present study thus focuses on the humor mechanism of written jokes through rhetorical and pragmatic perspectives.

Since humor is a complex and paradoxical phenomenon, it needs multiple approaches of analysis in investigating the multiple layers of meanings it carries. Among these approaches are pragmatic and rhetorical analyses, or popularly known as Pragma-Rhetoric (Larrazabal \& Korta, 2005); as humor may serve more than one rhetorical function, so it may fall under more than one humor theory (Meyer, 2000).

Humorous texts may be categorized as complex communicative acts which draw upon certain mental process both in their production and their reception, and which are therefore open to pragmatics. Rhetoric is regarded as the entire range of resources that human beings share for producing effects on one another; these effects can be ethical (including everything about character), practical (including political), emotional (including aesthetic), and intellectual (including every academic field). It is the entire range of use of "signs" (Booth, 2004, p. xi) for communicating, effectively or sloppily, ethically or immorally. It accounts for the specific features of texts that cause them to be meaningful, purposeful, and effective for readers or listeners. These features relate to diction, syntax, figurative language, organization, structure, and style.

A well-known source for verbal humor in the forms of short humorous texts is the Reader's Digest. The website Reference for business, in fact, states that the magazine is the world's most widelyread magazine with a global readership of more than 100 million and is available in 48 editions and 19 languages. This is owed in part to its transgenerational appeal as well as its ability to cross social, economic, and cultural boundaries in its target audience. In each edition it presents several humor sections under the headings of 'Laughter!', 'All in a day's work', and 'Life's like that'. Every year it publishes a humor special edition.

Other sources for such joke texts are www.ajokeaday.com and www.jokes.com, which are among the Top Ten List of Best Joke Sites on the Internet. These internet websites have enabled jokes to spread much faster and wider than ever. They are websites containing hundreds of jokes with various themes and are regularly updated. The best joke of the day is usually featured on the front page and several more are waiting for readers' votes on the "all submissions" site. They can also be subscribed to by emails.

These three sources were used as data sources in this study. The present study aims to characterize rhetoric and pragmatic mechanisms that are involved in the production and comprehension of the verbal jokes. Specifically, the study aims to address the following questions: how are the (1) rhetorical and (2) pragmatic strategies used in the jokes, and (3) how do pragmatic and rhetorical strategies complement to create humor?

The study thus intends to empirically examine the different ways in which humor is manifested linguistically in the written discourse and how it is rhetorically structured, analyzing the pragmatic function it plays, the process how the language is manipulated, how its interpretations are arrived at, and what humorous effects result from the social interaction.

\section{Pragmatics and the Rhetoric of Jokes}

Originally humor is derived from the Latin word "humorem/umorem" for "liquid" or "fluid". In early western physiology theory, humor was considered to be the four fluids of the body: blood (representing heat), phlegm (representing cold), choler (representing dryness), and melancholy (representing moisture). The mixture of these four "humors" in persons was thought to determine their physical and mental qualities (Dunping, 2005).

Humor is an important tool to achieve certain purposes. Verbal humor is a type of language behavior. Attardo (2003) defines humor by two criteria; (1) whether the event elicits laughter or smiling; (2) whether it was produced with the intention of eliciting laughter or smiling. Additionally, there are three kinds of humorous discourse: (1) universal jokes, (2) cultural jokes, and (3) linguistic jokes. A universal joke is humor that is obtained mainly from the context and the general functioning of the world. A cultural joke is humor that requires cultural background knowledge to understand and to appreciate, while a linguistic joke is humor created based on specific features in the phonology, morphology or syntax of particular languages (Schmitz, 2002).

Humorous discourse or jokes have these two characteristics: (1) they are narrative texts and (2) they are structured in the following way: introduction/ orientation, the chunk of text used by the author to introduce the characters, the place and time in which the story takes place; a possible dialogue between the characters or a series of events, and finally the punch line namely the end utterance that aims at provoking laughter. The introduction and dialogue refer to what in earlier conceptions were called build-up. The last part is the punchline or humor twist which closes the narration of the joke (Dynel, 2009, p. 10).

To analyze a humorous discourse, a combination of pragmatic and rhetorical perspectives can be employed to disclose the intentional phenomena that occur in most communicative uses of language, namely, the 
communicative intention and the intention of persuading. Much of the work in current pragmatics views linguistic understanding as the process of recognition of the speaker's communicative intentions. The addressee relies on linguistic and extralinguistic information for reaching that recognition. The ulterior perlocutionary effects on the audience, intended or not intended by the speaker, are usually ignored by pragmatic studies. This is where rhetoric can make its contribution. Persuasive as well as convincing and other kinds of perlocutionary intentions seem to constitute the basis of rhetorical studies of linguistic use (Larrazabal \& Korta, 2005).

There are many theories explaining the mechanisms by which humor is created. The principal theories of humor can be classified into three main groups: superiority theory, relief theory, and incongruity theory. The superiority theory maintains that humor stems from enhanced selfesteem based on the recognition of the target's infirmities, foibles, weaknesses or misfortunes. The relief theory, however, points that humor is used mainly to overcome socio-cultural inhibitions and reveal suppressed desires, whereas the incongruity theory states that humor is created out of a violation of an expectation. For humor to result from this unexpected circumstance, the event must have an appropriate emotional climate, comprised of the setting, characters, prior discourse, relationships of the characters, and the topic (Schwarz, 2010).

The selected joke texts being investigated in this study use various rhetorical techniques. It draws on the taxonomy of Berger (1993) to understand the jokes' rhetorical elements and ultimately linking those rhetorical elements with the proposed humor theories. This study also employed Grice's Cooperative Principle and accompanying maxims as the underlying theory to investigate the relationship between the creation of humor in the selected joke texts and the violation of the cooperative principle.

\section{METHOD}

Since the main focus of the present study is to analyze and describe jokes, the study is thus qualitative in nature. Specifically, it drew on discourse and conversation analyses, as it examined texts as "objects" in order to discover the rhetorical and pragmatic strategies used in the jokes.

The main data of the present study are the rhetoric and pragmatic features of narrative discourse composed of conversations and narration. They were obtained from the selected written-joke texts in Reader's Digest of Asian Edition of 20112013 editions in the sections 'Laughter', 'All in a day's work', and 'Life's like that', as well as from online sources www.ajokeaday.com and www.jokes.com. The data were collected through document studies and were then analyzed using a qualitative content analysis.

\section{FINDINGS AND DISCUSSION}

\section{The Rhetorical Strategies}

The analysis of the rhetorical strategies showed that there were basically three types of humorous discourse found in the jokes: (1) universal, (2) socio-cultural and political discourse, and (3) linguistic jokes. They were presented in various themes or categories, such as business/work, college/education, ethnic, family/marriage, kids, man vs. woman, political, puns, technology, and so forth. Table 1 presents the types of humorous discourse.

As seen in Table 1, joke (1) is characteristically a universal joke, meaning that anyone can understand and relate to them. It tells about how three people were taking a memory test. Their responses "274", "Tuesday", and "Nine" to the doctor's question "What's three times three?" showed that they had a severe problem with their memory. The responses "274" and "Tuesday" are not the correct answer; they are even ridiculous. The response "274" seems a miscalculation, whereas the response "Tuesday" is illogical because it refers to the name of day, not a number. The response "nine" seems promising; however, when asked "How did you get it?", the man responded "Easy, I subtracted 274 from Tuesday, " which is totally out of mind.

This message is generally understood and shared not only among people of one nationality but of all different ones. This joke belongs to the universal type. It is in line with what Schmitz (2002) has stated that a universal joke is humor obtained mainly from the context and the general functioning of the world. It is universally understandable as it employs reasoning and thinking in a counter-logical way to create a sense of humor, and reasoning and thinking in a logical way is common to all people.

One of the socio-cultural and political jokes is found in joke (2). Joke (2) is a political joke. It depicts what a political leader, George Bush, did to impress the boy by sending him a $\$ 5.00$ bill. What the boy responded was incongruous as, instead of thanking to the leader, he complained that he should have gotten more than that, i.e., $\$ 100.00$ bill, and said that it was because the government officer cut it. The truth was Mr. Bush sent the bill thinking that a $\$ 100$ bill was too much for a little boy like him. This is consistent with Schmitz's classification of jokes (2002) because the interpretation of this joke is context-dependent and is open to personal interpretation of situational meaning as different societies have different cultures, each culture has its own set of rules, values, and norms of what is appropriate and acceptable in humor.

Joke (3) is a linguistic joke. It uses a phonological element to create the joke. In this joke, 
"911" is pronounced "nine-one-one" and never "nine eleven". Therefore the funny part of the joke lied in the answer "She can't find the eleven." It is in line with Schmitz' s classification of jokes (2002) that this kind of joke is the rhetoric devicedependent humor, whose funny effect derives directly from the language itself due to the clever use of rhetorical devices like pun.

The type of humorous discourse is one of the rhetorical strategies used in the jokes. Another found in this study deals with a rhetorical structure known as joke structure. The analysis reveals that the jokes have the structure of a narrative text. The structure mainly covers two parts: the build-up and the punch-line. The build-up consists of an introduction and dialogues or events which usually function as the jab-line. They differ in the frequency of the events in each text. Table 2 shows examples of a joke structure.

Table 1. Types of Humorous Discourse

\begin{tabular}{l} 
No. Discourse Types \\
\hline Universal \\
Three friends are taking a memory test. The doctor asks the first man, "What's three \\
times three?" \\
"274," the first man replies. \\
"Hmm," the doctor replies, then turns to the second man: "What's three times \\
three?" "Tuesday," the man lies. \\
Finally, the doctor to the third man asks, "What's three times three?" \\
Nine." \\
Great!" the doctors. "How did you get it?" ("Easy," the man explains. "I subtracted \\
274 from Tuesday."
\end{tabular}

(Reader's Digest, February 2011, p. 57)

\begin{tabular}{|c|c|c|}
\hline 2 & $\begin{array}{l}\text { Socio-cultural and } \\
\text { political }\end{array}$ & $\begin{array}{l}\text { Little Billy wanted } \$ 100 \text { badly and prayed for two weeks but nothing happened. } \\
\text { Then he decided to write God a letter requesting the } \$ 100 \text {. When the postal } \\
\text { authorities received the letter addressed to God, USA, they decided to send it to } \\
\text { President Bush. } \\
\text { The President was so impressed, touched, and amused that he instructed his } \\
\text { secretary to send Billy a } \$ 5.00 \text { bill. } \\
\text { President Bush thought this would appear to be a lot of money to a little boy. } \\
\text { Billy was delighted with the } \$ 5.00 \text { and sat down to write a thank you note to God, } \\
\text { which read: } \\
\text { Dear God, } \\
\text { Thank you very much for sending the money, however, I noticed that for some } \\
\text { reason you had to send it through Washington D.C. and, as usual, those crooks } \\
\text { deducted } \$ 95.00 . \\
\text { Thanks, } \\
\text { Billy }\end{array}$ \\
\hline 3 & Linguistic & $\begin{array}{l}\text { Q: Why can't a blonde dial } 911 ? \\
\text { A: She can't find the eleven. }\end{array}$ \\
\hline
\end{tabular}

As shown in Table 2, the introduction or the scene orientation is when "Three friends are taking a memory test. The doctor asks the first man, "What's three times three?". There are three events in Joke (1). The first event is when the doctor asked the first man and the man replied, "274". The second event is when the doctor asked the second man and he responded, "Tuesday". The third event is when the doctor asked the last man replying "Nine". The punch-line or humor twist lies in the surprising response of the last man that he got "Nine" by actually subtracting 274 from Tuesday. This structure is consistent with Dynel's (2009) model of joke structure, i.e., the scene orientation, a sequence of events, and humor twist. The orientation provides the background for the text and introduces the participants involved in the text. The events tell the readers about the sequence of events happening in the text, while the twist contains the humorous punch line of the text. The last element provides a humorous ending for the text so that the readers will be entertained at the end of the reading. It also realizes the social function of the humorous texts that is to entertain the reader.

What is reflected in the analyzed joke texts is consistent with what Anderson and Anderson (1997) have suggested - that a typical structure of a humorous narrative include orientation, complication, sequence of events, and resolution. The orientation introduces funny character names or unusual setting. The complication tells that 
something 'crazy' happens. The sequence of events can be funny thing related to the characters, imaginative ideas, extraordinary things happening to ordinary people, making fun of serious situations, exaggeration, or comedy of errors. The resolution shows how the characters sort out the complication. In this way, humorous results can be achieved.

In addition to the type and structure of humorous discourse, the other rhetorical strategy used in the jokes is the rhetorical devices or tools to create the jokes. The major devices include (a) irony/sarcasm, (b) exaggeration, (c) misunderstanding, (d) satire, and (e) puns and wordplay. Table 3 shows the humor devices.

As revealed in Table 3, there are mainly five kinds of humor devices used in the jokes: (a) irony/sarcasm, (b) exaggeration, (c) misunderstanding, (d) satire, and (e) puns and wordplay. In Joke (4), the humor device used is irony. The fact that the chauffeur acting as Einstein asked Einstein to answer the difficult question is ironic ("Sir, the answer to your question is so easy that I'll let my chauffeur answer it!"). This is in line with Berger's (1993) humor techniques that irony in humor uses language to imply the opposite of their literal meaning or a situation where the outcome is the opposite from that intended or expected.

Joke (5) is an exaggeration. It works by first evoking a fairly common, day-to-day image, and then exaggerating one or more aspects of that image to become ridiculous and funny (Berger, 1993). In this joke, the set up has people imagining small towns with which they are familiar. Images of a single gas station, no traffic lights, and a general lack of activity come to mind. The punch line comes by exaggerating all of the concepts that people have of small towns to an absurd extreme.

Joke (6) contains a misunderstanding. In this joke, the lawyer thought that the doctor and the priest would be giving their donation, but they did not. The lawyer had written the check for $\$ 50,000$ and threw it into the grave ("I am surprised at you two for taking advantage of him like that. I wrote a check for the full amount and threw it all in!!!").
This is adherent to Berger's (1993) humor techniques that misunderstanding is usually caused by "bad judgment, lack of knowledge, or sheer stupidity" (p. 59).

Joke (7) is satirical. Satire occurs when humor exposes silliness, foolishness or stupidity through ridicule. In this joke, the construction worker showed his stupidity by saying that his ear should have a pencil behind it. In fact, it must have been his ear found by a passer-by. This is in line with Berger's (1993) humor techniques that mock human weaknesses or aspects of society.

\section{The Pragmatic Strategies}

Next is the analysis of communicative intention of the jokes from pragmatic perspectives. The analysis first considered the major proponents of 'speech act theory' and their ideas about meaning assignment. This opened up the possibility of there being a difference between the meaning of certain words (x) and what the speaker intended to convey by using those words. Grice (1957) and Dascal (1985) regarded this as humorous intent and that jokes depend on the existence of these sociopragmatic devices that make indirectness possible. These can be discovered from three different levels of meaning: (a) sentence meaning: understanding a speaker's words (b) utterance meaning: understanding those words in their specific reference in the context of the utterance, (c) speaker's meaning: the speaker's intention of uttering those words in that context. Speaker's meaning can be conveyed in two different ways: directly or indirectly. It is direct when it is identical to the utterance meaning; in this case pragmatic interpretation can be seen as the 'endorsement' of the utterance meaning by the listener. It is indirect when it is different from the utterance meaning, and the pragmatic interpretation is constructed by drawing on the cues in the context and by using the utterance meaning as a starting point.

The analysis indicates that there are various humorous intents found in the jokes, as shown in Table 4.

Table 2. Joke Structure

\begin{tabular}{|c|c|c|c|}
\hline Joke No. & \multicolumn{2}{|c|}{ Structure Elements } & Sample Narration/Dialogue of the Joke \\
\hline \multirow[t]{3}{*}{1} & a. build-up & 1) introduction & $\begin{array}{l}\text { Three friends are taking a memory test. The doctor asks the } \\
\text { first man, "What's three times three?" }\end{array}$ \\
\hline & & 2) dialogue/events & $\begin{array}{l}\text { a) "274," the first man replies. } \\
\text { b) "Hmm," the doctor plies, then turns to the second man: } \\
\text { "What's three times three?" "Tuesday," the man lies. } \\
\text { c) Finally, the doctor to the third man asks, "What's three } \\
\text { times three?" } \\
\text { Nine." }\end{array}$ \\
\hline & b. punch-lin & & $\begin{array}{l}\text { Great!" the doctors. "How did you get it?" ("Easy," the } \\
\text { man explains. "I subtracted } 274 \text { from Tuesday." }\end{array}$ \\
\hline
\end{tabular}


Table 3. Humor Devices

\begin{tabular}{|c|c|c|}
\hline Joke No. & Humor Devices & Sample Narration/Dialogues Showing the Device \\
\hline 4 & 1. irony/sarcasm & $\begin{array}{l}\text { Einsteinium } \\
\text { Albert Einstein used to go to dinners where he was invited to give a speech. One day, } \\
\text { on his way to one of those dinners, he told his chauffeur (who looked exactly like } \\
\text { him) that he was dead tired of giving the same speech, dinner after dinner. } \\
\text { "Well," said the chauffeur, "I've got a good idea. Why don't I give the speech since } \\
\text { I've heard it so many times?" So Albert's chauffeur gave the speech perfectly and } \\
\text { even answered a few questions. Then, a professor stood up and asked him a really } \\
\text { tough question about anti-matter which the chauffeur couldn't answer } \\
\text { "Sir, the answer to your question is so easy that I'll let my chauffeur answer it!" } \\
\text { (http://jokes.cc.com/funny-school-jokes/wmlo80/einsteinium) }\end{array}$ \\
\hline 5 & 2. exaggeration & $\begin{array}{l}\text { Johnny Carson: You know, I was visiting a small town last week. } \\
\text { His friend: How small was it? } \\
\text { Johnny Carson: The Enter and Exit signs for the town were on the same pole. } \\
\text { (http://www.toddstrong.com/comedywriting/exaggeration.php) }\end{array}$ \\
\hline 6 & 3. misunderstanding & $\begin{array}{l}\text { An elderly man, } 82, \text { just returned from the doctors only to find he didn't have long to } \\
\text { live. So he summoned the three most important people in his life to tell them of his } \\
\text { fate: } \\
\text { 1. His Doctor } \\
\text { 2. His Priest } \\
\text { 3. His Lawyer. } \\
\text { He said, "Well, today I found out I don't have long to live. So, I have summoned you } \\
\text { three here, because you are the most important people in my life, and I need to ask a } \\
\text { favor. Today, I am going to give each of you an envelope with } \$ 50,000 \text { dollars } \\
\text { inside. When I die, I would ask that all three of you throw the money into my grave." } \\
\text { After the man passed on, the three people happened to run into each other. The } \\
\text { doctor said, "I have to admit I kept } \$ 10,000 \text { dollars of his money. He owed me from } \\
\text { lots of medical bills. But, I threw the other } \$ 40,000 \text { in like he requested. "The Priest } \\
\text { said, "I have to admit also, I kept } \$ 25,000 \text { dollars for the church. It's all going to a } \\
\text { good cause. I did, however, throw the other } \$ 25,000 \text { in the grave." Well the Lawyer } \\
\text { just couldn't believe what he was hearing! "I am surprised at you two for taking } \\
\text { advantage of him like that. I wrote a check for the full amount and threw it all } \\
\text { in!!!"' } \\
\text { (http://www.ajokeaday.com/Clasificacion. asp?ID=43\&Pagina=2\#ixzz3JQY3jQbj) }\end{array}$ \\
\hline 7 & 4. satire & $\begin{array}{l}\text { Ear Accident } \\
\text { A construction worker accidentally cuts off one of his ears with an electric saw. } \\
\text { He calls out to a guy walking on the street below, "Hey, do you see my ear down } \\
\text { there?" } \\
\text { The guy on the street picks up an ear and yells back, "Is this it?" } \\
\text { "No," replies the construction worker. "Mine had a pencil behind it." } \\
\text { (http://jokes.cc.com/funny-work-jokes/8mmabc/ear-accident) }\end{array}$ \\
\hline 8 & 5. puns and wordplay & $\begin{array}{l}\text { Maurice an } 82 \text { year-old man went to the doctor for his physical. } \\
\text { A few days later the doctor saw Maurice walking down the street with a gorgeous } \\
\text { young lady on his arm. } \\
\text { A couple of days later do doctor spoke to Maurice and said, "You're really doing } \\
\text { great, aren't you?" } \\
\text { Maurice replied, "Just doing what you said, Doc: "Get a hot mamma and be } \\
\text { cheerful." } \\
\text { The doctor said, "I did not say that. I said, “You got a heart murmur. Be careful." } \\
\text { (http://www.ajokeaday.com/ChisteDelDia.asp\#ixzzJJQV4Yuuj) }\end{array}$ \\
\hline
\end{tabular}

There are mainly four types of humorous intents that are in accordance with Searle's (1985) types of speech acts: (a) to assert, conclude, describe - representatives, (b) to promise, offercommisives, (c) to request, question, orderdirectives, and (d) to thank, apologize-expressive. In Joke (9), in saying "It's running down in my leg." Wilfred is performing the locutionary act of saying those words, and he is also performing the illocutionary act of informing the teacher that something is running down his leg ("P") and perhaps the act of telling that he is having " $P$ " the teacher is asking. In fact, he intends to be performing the perlocutionary act of causing the teacher to believe that he knows that he missed to mention "P". He is performing all these speech acts just by uttering certain words. Thus, Joke (9) has a representative humorous intent, i.e., to inform. 
Table 4. Humorous Intents

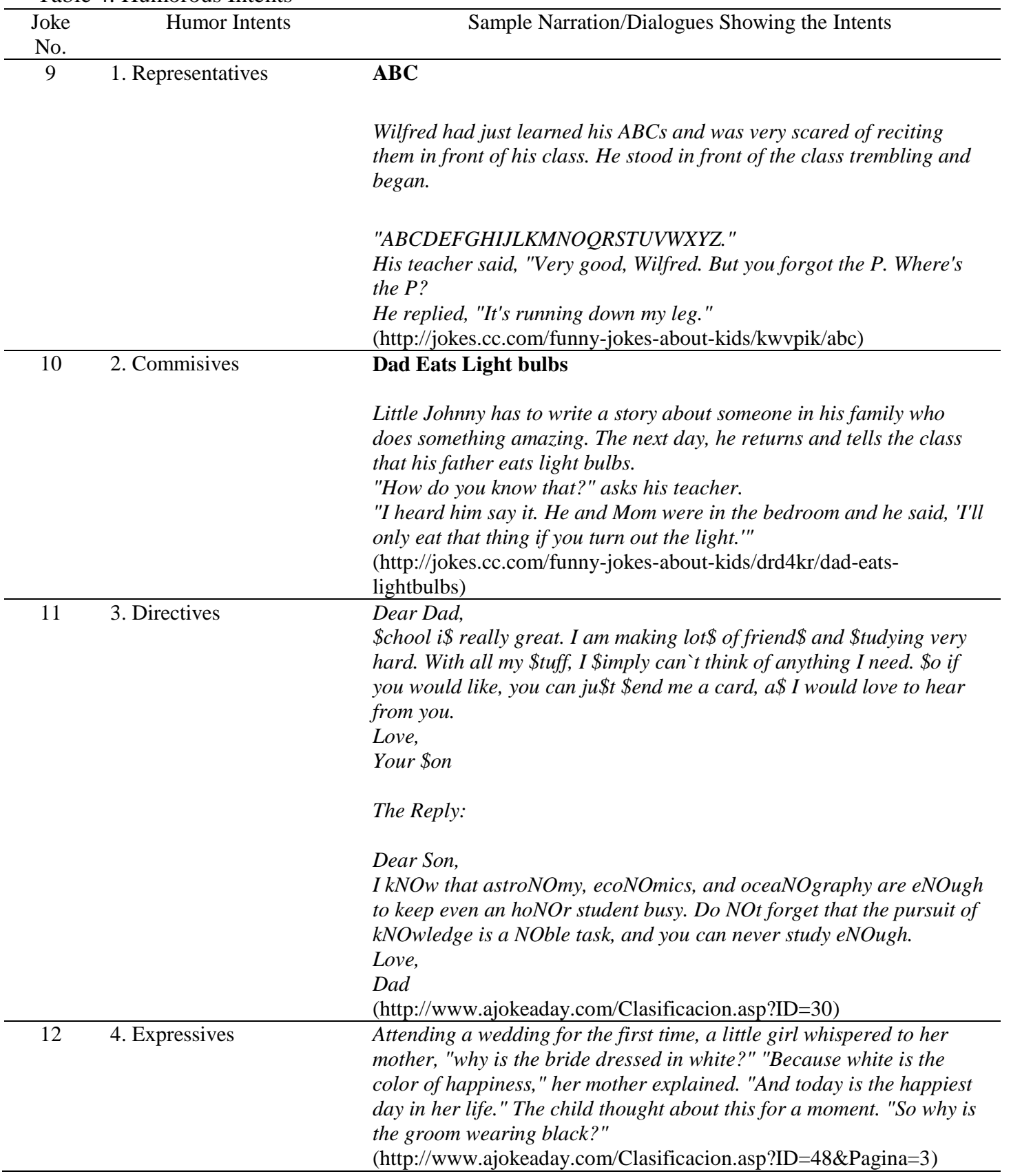

There are also some other humorous intents under this category. They include affirming, alleging, announcing, answering, attributing, claiming, classifying, concurring, confirming, conjecturing, denying, disagreeing, disclosing, disputing, identifying, informing, insisting, predicting, ranking, reporting, stating, stipulating.

Joke (10) has a commisive humorous intent; a commissive is any speech act that involves the speaker committing himself to behave in some required way. In this case, the joke is intended to promise, as in "I'll only eat that thing if you turn out the light." In this instance, the father's promise was used to trigger the joke. Some other humorous intents found in the jokes covered: agreeing, guaranteeing, inviting, offering, promising, swearing, and volunteering.

Joke (11) is a directive type, as it has an imperative mood ("\$o if you would like, you can ju\$t \$end me a card", asking his father to send him his credit card). Thus, it is in line with Searle's (1985) types of speech act, in that a directive is any speech act that involves the speaker trying to get the hearer to behave in some required way. Other humorous intents workable in the jokes are advising, admonishing, asking, begging, dismissing, excusing, forbidding, instructing, ordering, permitting, requesting, requiring, suggesting, urging, and warning.

Joke (12) belongs to an expressive speech act, as it corresponds to an attitude being expressed in 
the joke. It expresses the child's curiosity why the bride was in white whereas the groom was wearing a black suit. The other humorous intents in the jokes relate to apologizing, condoling, congratulating, greeting, thanking, accepting.

The examples considered thus far suggest that performing a speech act, in particular an illocutionary act, is a matter of having a certain communicative intention in uttering certain words; in this instance, it is humorous intent. Such an act succeeds, if the audience recognizes that intention. It follows that people must choose their words in such a way that their utterances make the humorous intention recognizable.

To crack humorous meaning, the three meanings (utterance, sentence, and speaker's meanings) must be understood, as modelled by Dascal (1985) and Willis (2003). As previously mentioned, speaker's meaning can be conveyed either directly or indirectly. Jokes systematically exploit indirectness; they point to a preferred meaning (M1) and this must be done indirectly, for to make M1 too explicit would not allow the alternative meaning (M2) to be recoverable. This indirectness about M1 means that such an interpretation is actually contributed by the listener more than the speaker himself. In fact, the listener construes that interpretation in the course of hearing the joke, and expects the rest of the story to confirm her/his interpretation. The comic effect arises when an alternative, non-favored and therefore non-expected interpretation is revealed, at the punch line, as the correct one.

This humorous interpretation mechanism is presented in Figure 1. Joke (12) is taken as an example:

The kid wondered why a bride always wore a white gown representing the happiest moment in her life as her mother explained. He then asked her why a groom always wore a black suit.

The bride was very happy

Thesis (M1)

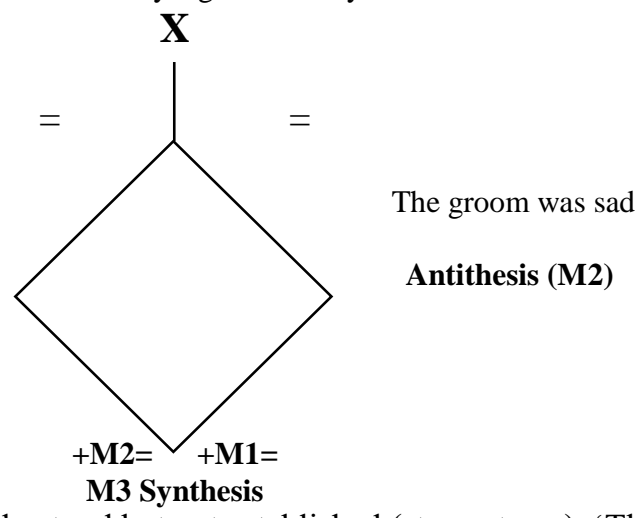

'The bride was very happy' is implicitly understood but not established (strong trace). 'The groom was sad' is explicitly understood and established.

Figure 1. Diagrammatic representation of Dascal's (1985) model of utterance interpretation and Willis' (2003) joke resolution: The strong trace

Another pragmatic perspective suggests that humor has been created by violating Grice's (1957) maxims of cooperation, namely the maxims of Quality, Quantity, Manner and Relevance. These maxims are helpful to reveal what is said to what is meant, from the level of expressed meaning to the level of implied meaning (Grice 1989). A large number of jokes present a violation of one of the four maxims (Attardo, 1994). Table 5 shows more closely the connection between humor and the maxims.

Table 5 reveals that all the maxims are violated in the series for humorous purposes either deliberately or by mistake. Joke (13), for instance, had a violation of maxim of Quality. The maxim was violated by the character in the joke, i.e., the blonde, by saying "It wouldn't sit still!", which was in fact false. It was done by mistake. The maxim is violated fairly regularly throughout the whole jokes, mainly by characters saying something they know to be false; e.g., by simply lying, by exaggerating or by using figurative language that does not comply with the reality of the jokes.

Another is a violation of maxim of Quantity as in Joke (14). The maxim was violated by the addressee when he gave the sarcastic answer "Anything you want, he can't hear you!" to the silly question "What do you call a polar bear with ear muffs?" The maxim of Quality is violated also unintentionally several times in the jokes mainly by stating something that the character him/herself believes to be true, but the other characters in the exchange know it to be false, whether by mistake or misunderstanding. 
Table 5. Maxim Violations in the Jokes

\begin{tabular}{|c|c|c|}
\hline $\begin{array}{c}\text { Joke } \\
\text { No. }\end{array}$ & Maxim Violation & Expressions containing the violation \\
\hline 13 & Quality & $\begin{array}{l}\text { It was the first time a blonde was eating Thanksgiving dinner } \\
\text { without her family, so she prepared a dinner by herself. } \\
\text { The next day, her mother called to see how everything went. } \\
\text { "Mom, I made myself a lovely dinner, but I had so much trouble } \\
\text { trying to eat the turkey!" the blonde said. } \\
\text { "Did it not taste good?" her mother asked. } \\
\text { "I don't know," the blonde replied. "It wouldn't sit still!" } \\
\text { (http://jokes.cc.com/) }\end{array}$ \\
\hline 14 & Quantity & $\begin{array}{l}\text { Q. What do you call a polar bear with ear muffs? } \\
\text { A. Anything you want, he can't hear you! } \\
\text { (http://www.ajokeaday.com/ChisteDelDia.asp) }\end{array}$ \\
\hline 15 & Relevance & $\begin{array}{l}\text { Q: Why did the blonde take a right into the ditch? } \\
\text { A: Her blinker was on. } \\
\text { (http://jokes.cc.com/funny-travel---car-jokes/3fll183/blonde-driver) }\end{array}$ \\
\hline 16 & Manner & $\begin{array}{l}\text { "Honey," said this husband to his wife, "I invited a friend home for } \\
\text { supper." } \\
\text { "What? Are you crazy? The house is a mess, I didn't go shopping, } \\
\text { all the dishes are dirty, and I don't feel like cooking a fancy meal!" } \\
\text { "I know all that." } \\
\text { "Then, why did you invite a friend for supper?" } \\
\text { "Because the poor guy is thinking about getting married." } \\
\text { (http://www.ajokeaday.com/ChisteDelDia.asp) }\end{array}$ \\
\hline
\end{tabular}

The maxim of Relevance is also violated in Joke (14). It occurred when the addressee responded "Her blinker was on" irrelevantly to the question "Why did the blonde take a right into the ditch". The maxim of Relevance is also violated throughout the jokes, but not as extensively as the two former. The maxim of Relevance, on the other hand, can be seen to operate on two levels; that of the reality of the jokes, and the reality of the reader. The irrelevant absurdities the characters often utter comply with the reality of the series as it is intended to be irrelevant and thus funny and relevant, but from the perspective of the "real" reality, much of what the characters say is irrelevant.

The last is a violation of the maxim of Manner. This is mainly achieved by using extremely meandering language; being brief and orderly had clearly not been a goal for the writers of the jokes, as in Joke (15), since what the husband is actually saying "Because the poor guy is thinking about getting married." remains fairly obscure. It clearly is not as brief as could be. What he is actually saying is that their marriage was a mess and would like to suggest the poor guy that he should reconsider his desire to marry.

\section{The Rhetorical and Pragmatic Strategies for Humor Analysis}

As previously mentioned, the rhetoric and pragmatic strategies can be combined for humorous discourse analysis. The combination of both disciplines is used to reveal the linguistic manifestation and intentional phenomena that occur in most communicative uses of language, such as those in jokes. The rhetoric strategies are applied to crack the linguistic devices and the pragmatic ones deal with the "basic intentional components that have to be considered in relationship with emotive components and any other psychological aspect of speakers and hearers, changing alternatively their roles in the production of discourses." (Larrazabal \& Korta, 2006, p. 8).

Joke (16) can be approached with the combined strategies:

Working in a library, one of the tasks we have to do twice a week is call patrons about their overdue items. One day, I had to call someone about a late book titled: Don't Forget Easy Exercises for a Better Memory. - Joyce Tenhage (Reader's Digest, February 2011, p. 12)

Rhetorically, Joke (16) is ironic. To be more specific, it is a situational irony (Ortega, 2013). It is characterized by contrast between what actually occurs (the patron has forgotten his/her overdue book) and what is expected (the patron should not have forgotten it since he/she had been borrowing the book on easy exercises for a better memory).

The joke additionally illustrates its structure in presenting the humor. The structure includes the build-up (the librarian described his/her work) and the punchline (the librarian called to remind the patron of the overdue book). The function of the build-up is to start the joke and lead directly to understanding and to decode the punchline as the comic trigger.

Once the joke's rhetorical structure is understood, a reader can then comprehend the underlying messages within the discourse-the humorous intent. The humorous intent is "the actual message a speaker hopes to express regardless of the literal semantics of the sentences he or she employs" (Cheang \& Pell, 2006, p. 447). 
The intended, non-literal meaning of the humorous intent of the punchline in Joke (16) can be revealed through its illocutionary act. It includes (1) representative, in that the narrator conveys the description of his or her daily work as a librarian and at the same time, (2) expressive, as the narrator expresses his or her ridiculing the patron's odd behavior.

To sum up, the rhetorical and pragmatic views of the English-written jokes can help readers to understand the humorous meanings. Both of the strategies are complementary (Larrazabal \& Korta, 2006). The rhetorical perspectives are helpful in understanding the joke structure, while the pragmatic aspect can help readers to reveal the humorous intentions.

\section{CONCLUSION}

Based on the analyses, it can be concluded that humor can be created and function in various ways. These different functions, in turn, may create different effects in the readers. It is also interesting to discover that there is a relationship between the two major pragmatic theories, i.e., Speech Act Theory (1975) and Cooperative Principles (1957), and Berger's (1993) rhetorical techniques. They interconnect and are together able to bring forward a more coherent picture of the humor in the data. Due to the different nature of maxims, they co-occur with certain rhetorical techniques in the humorous texts. The violation of the maxim of Quality (for example lying) co-occurs often with irony or sarcasm. This is hopefully a valuable contribution to the field of linguistic studies in humor research.

These findings have several implications for instructional values, both in general education and in second language teaching and learning. In the general education context, the teaching of jokes can gain and keep students' attention, increase their motivation and retention of materials, and relax their classroom environment (Wanzer, 2002).

In relation to the teaching and learning of a second language, the teaching of jokes can be incorporated into the instruction of all four main language skills. Jokes such as wordplays, funny stories, puns, and content-related ones can also serve as a versatile tool that can be used for sensitizing students to phonological, morphological, lexical, and syntactic differences within a single language or between a student's native language and the target language. In addition, the cultural content embedded in jokes can be used to enhance their intercultural understanding (Ziyaeemehr, Kumar \& Abdullah, 2011).

Finally, understanding the language of written jokes, in particular linguistic ambiguity, puns and wordplay, and culture-specific references requires the so-called resolution mechanism (Bucharia, 2004) applied by readers. It is therefore suggested that this mechanism should be further investigated to reveal how readers perceive and comprehend the jokes as funny.

\section{REFERENCES}

Afidah,L., \& Wahyudi, R. (2014). How it starts and ends: A study of Indonesian stand-up comedy. Bahasa \& Sastra, 14(2), 170-190.

Al-Ameedi, R. T.K., \& Abdulmajeed, R.K., (2016). Persuasion in Jesus Christ's humour: A linguistic analysis. Open Journal of Modern Linguistics, 6, 71-84.

Anderson, M., \&Anderson, K. (1997). Text types in English 2. South Yarra: MacMillan Education Australia Pty Ltd.

Ashipaoloye, F. K. (2013). Integrating sense of humor as a teaching strategy among students of LPU Batangas. Asia Pacific Journal of Multidisciplinary Research. 1(1), 116-125.

Attardo, S. (2014). Humor in language. Retrieved $13^{\text {th }}$ April, 2017 from http://www.oxfordbibliographies.com/.

Attardo, S. (2003). Introduction: The pragmatics of humor. Journal of Pragmatics, 35, 1287-1294.

Attardo, S. (1994). The linear organization of jokes: analysis of two thousand texts. HumorInternational Journal of Humor Research, 7(1), 27-54.

Berger, A.A. (1993). Anatomy of humor. New Brunswick, N.J.: Transaction Publisher.

Booth, W.C. (2004). The rhetoric of rhetoric. Oxford: Blackwell Publishing Ltd.

Bucharia, C. (2004). Lexical and syntactic ambiguity as a source of humor: the case of newspaper headlines. Humor-International Journal of Humor Research, 17(3), 279-309.

Byran, M. (1989). Cultural studies in foreign language education. Clevedon, UK, Multilingual Matters Ltd.

Cheang, H. S., \& Pell, M. D. (2006). A study of humour and communicative intention following right hemisphere stroke. Clinical Linguistics \& Phonetics, August 2006; 20(6), 447-462.

Chetia, B. (2015). Rhetorical devices in English advertisement texts in India: A Descriptive Study. International Journal of Social Science and Humanity, 5(11), 980-985.

Dascal, M. (1985) Language use in jokes and dreams: Sociopragmatics vs. Psychopragmatics. Language \& Communication, 5(2), 95-106.

Dunping, L. (2005). Humor and conceptual blending. Unpublished Thesis. Anhui University.

Dynel, M. (2009). 'Beyond a joke: Types of conversational humour'. Language and Linguistics Compass 3, pp.1284-1299. 
Ermida, I., \& Chovanec, J. (2012). Humor, language, and the media. Newcastle upon Tyne: Cambridge Scholars Publishing.

Golchi, M. M. \& Jamali, F. (2011). The effect of teacher's verbal humor on advanced learners' classroom anxiety. European Journal of Social Sciences, 26(2), pp.185-192. Retrieved from http://www.europeanjournalofsocialsciences.c om, $2^{\text {nd }}$ February 2012.

Graf, A. (2003. Humour in Indonesian politics: A case study of the political marketing of Gus Dur. IIAS Newsletter, 31, 17.

Grice, H. P. (1989). Studies in the way of words. New York, Harvard University Press.

Hietalahti, J. (2016). Humor and disobedience: Understanding controversial humor. Filosofiska Notiser, Årgång, 3, 33-44.

Kao, J. T., Levy, R., \& Goodman, N. D. (2015). A computational model of linguistic humor in puns. Cognitive Science. Pp.1-16. Wiley Periodicals, Inc. DOI: 10.1111/cogs.1226

Kayam, O. (2014). Transformative rhetoric: How Obama became the new face of America: A linguistic analysis. Journal of Language and Cultural Education, 2(2), 233-251.

Kuipers, G.(2008). The sociology of humor. Berlin: Mouton de Gruyter.

Larrazabal, J. M., \& Korta, K. (2006). Pragmatics and rhetoric for discourse analysis: Some conceptual remarks. Retrieved $15^{\text {th }}$ January, 2009 from:

http://www.sc.ehu.es/ylwkocak/papers/Pragma tics\%20and\%20Rhetoric.pdf

Lesmana, M. (2015). Enjoying the texts of sexual humor in Indonesia. International Journal of Humanities and Social Science Invention, 4(5), 50-53.

Lin, A. M. Y. (2012). Critical practice in English language education in Hong Kong: Challenges

and possibilities. In K. Sung, \& R. Pederson (Eds.), Critical ELT Practices in Asia (pp. 7183). Rotterdam/Boston/Taipei: Sense Publishers.

Ma, Z. \& Jiang, M. (2013). Interpretation of verbal humor in the Sitcom The Big Bang Theory. Theory and Practice in Language Studies, 3(12), 2220-2226.
Meyer, J. C. (2000). Humor is double-edged sword: Four functions of humor in communication. Communication Theory, 10(3), 310-331.

Mwetulundila. R. \& Kangira, J. (2015). An analysis of rhetoric and humour in Dudley's political cartoons published in the Namibian newspapers in 2012. International Journal of Research in Humanities and Social Studies, 2(6), 63-75.

Ortega, M. B. A. (2013). An approach to verbal humor in Interaction. Procedia-Social and Behavioral Sciences, 95, pp. 594-603. DOI: 10.1016/j.sbspro.2013.10.687

Săftoiu. R., \& Popescu, C. (2014). Humor as a branding strategy in political discourse. A case study from Romania. Revista Signos. Estudios de Lingüística, 47(85), 293-320.

Schmitz, J. R. (2002). Humor as a pedagogical tool in foreign language and translation courses. Humor: International Journal of Humour, 15(1), 89-113.

Schwarz, J. ( 2010). Linguistic aspects of verbal humor in stand-up comedy. Dissertation, zur Erlangung des akademischen Grades einesDoktors der Philosophie der Philoso phischen Fakultäten der Universität des Saarlandes

Searle, J. (1985). Expression and meaning: Studies in the theory of speech acts. Cambridge: Cambridge University Press.

Sen, A. (2012). Humor analysis and qualitative research. Social Research Update, Issue 63, Summer 2012.

Shade, R. (1996). License to laugh: Humor in the classroom. Englewood, Colorado: Teacher Idea Press.

Wanzer, M. (2002). Use of humor in the classroom: The good, the bad, and the not-so funny things that teachers say and do. In Chesebro, J. L. \& J. McCroskey, J. C., (Eds.), Communication for Teachers, pp. 116-126. Boston: Allyn \& Bacon.

Willis, D. (2003). Rules, patterns and words. Cambridge: Cambridge University Press.

Ziyaeemehr, A., Kumar, V., \& Abdullah, M. S. F., (2011). Use and non-use of humor in academic ESL Classrooms. English Language Teaching, 4(3), 111-120. 